\title{
Clinical Efficacy and Safety of Tacrolimus in Pakistani Living Donor Liver Transplant Recipients
}

\author{
Fahad Azam1, Moosa Khan2, Abu Bakar Hafeez Bhatti3, Faisal Saud Dar3, Arsalan Ahmad4 and Nismat Javed 5 \\ IDepartment of Pharmacology and Therapeutics, Shifa College of Medicine, Shifa Tameer-e-Millat University, Islamabad, Pakistan \\ ${ }^{2}$ Department of Pharmacology and Therapeutics, Shaheed Zulfiqar Ali Bhutto Medical University, Islamabad, Pakistan \\ ${ }^{3}$ Department of Hepatobiliary and Liver Transplant, Shifa International Hospital, Shifa Tameer-e-Millat University, Islamabad, Pakistan \\ ${ }^{4}$ Department of Neurology, Shifa International Hospital, Shifa Tameer-e-Millat University, Islamabad, Pakistan \\ 5 Medical Student, Shifa College of Medicine, Islamabad, Pakistan
}

\begin{abstract}
Objective: To evaluate the association between tacrolimus trough levels and dosage in Pakistani patients undergoing live donor liver transplantation (LDLT), and the efficacy and adverse effects at different tacrolimus trough levels and dosages. Study Design: An observational study.

Place and Duration of Study: Shifa International Hospital, Shifa Tameer-e-Millat University, Islamabad and Basic Medical Sciences Institute, Karachi, from September 2016 to October 2018.

Methodology: Sixty liver transplant recipients were included. Demographics, clinical data, tacrolimus trough levels and doses were monitored as per routine protocol. Electrochemiluminescence immunoassay (ECLIA) was used to measure tacrolimus trough levels. Acute cellular rejection (ACR), sepsis and other adverse events were monitored at different tacrolimus trough levels in early post-transplantation period.

Results: Mean age of transplant recipients was $49.1 \pm 10.6$ years. Mean tacrolimus trough levels were $6.1 \pm 2.2 \mathrm{ng} / \mathrm{ml}$ and mean dose was $0.94 \pm 0.3 \mathrm{mg}$. Sepsis $(27 \%)$ psychosis $(20 \%)$, seizures $(10 \%)$, and renal insufficiency $(13 \%)$ were the most common adverse effects. Acute cellular rejection (ACR) was observed in $15 \%$ patients. Patients with sepsis had significantly high mean tacrolimus levels of $7.7 \pm 2.5 \mathrm{ng} / \mathrm{ml}$ versus $5.5 \pm 1.9 \mathrm{ng} / \mathrm{ml}(\mathrm{p}=0.001)$. Mean tacrolimus trough levels in patients with ACR were significantly lower $(4.05 \pm 1.6 \mathrm{ng} / \mathrm{ml}$ vs. $6.43 \pm 2.2 \mathrm{ng} / \mathrm{ml}, \mathrm{p}=0.003)$. None of the patients with a single tacrolimus trough level $>10 \mathrm{ng} / \mathrm{ml}$ experienced ACR.

Conclusion: A tacrolimus trough level between 5 to $7.5 \mathrm{ng} / \mathrm{ml}$ appears to be safe in Pakistani liver transplant recipients significantly minimising the risk of ACR and other adverse events.
\end{abstract}

Key Words: Tacrolimus, Liver transplant, Adverse effects, Immunosuppression.

How to cite this article: Azam F, Khan M, Bhatti ABH, Dar FS, Ahmad A, Javed N. Clinical efficacy and safety of tacrolimus in Pakistani living donor liver transplant recipients. J Coll Physicians Surg Pak 2019; 29(11):1048-52.

\section{INTRODUCTION}

Liver transplantation is a life-saving treatment for patients with end-stage liver diseases. 1 In the United States alone, liver transplantation was performed on eight thousand patients suffering from end-stage liver disease in 2017.2 Pakistan with its population over 180 million has a prevalence of $2.4 \%$ for hepatitis $B$ virus (HBV) and $6.2 \%$ for hepatitis $\mathrm{C}$ virus (HCV) infection. These are major risk factors for liver cirrhosis and hepatocellular carcinoma.3,4 Due to high burden of HCC and liver failure, living donor liver transplant (LDLT) is a viable treatment option for these patients. ${ }^{5}$

Alongside advances in surgical technique and postoperative supportive care, the use of potent immuno-

Correspondence to: Dr. Fahad Azam, Department of

Pharmacology and Therapeutics, Shifa College of Medicine,

Shifa Tameer-e-Millat University, Islamabad, Pakistan

E-mail:fahad.scm@stmu.edu.pk

Received: April 29, 2019; Revised: August 07, 2019;

Accepted: September 11, 2019 suppressive agents has made this procedure safer by preventing and treating acute and chronic rejection. ${ }^{6}$ Calcineurin inhibitors $(\mathrm{CNI})$ based drug regimens are mainstay of immunosuppressive protocols in patients undergoing liver transplantation. Both tacrolimus and cyclosporine are calcineurin inhibitors and bind to their specific ligands, immunophilin FK-binding protein and cyclophilin respectively; which eventually suppress immune response by inhibiting activation of T-cell specific transcription factor NF-AT and transcription of multiple cytokine genes. 7,8

Calcineurin inhibitors have a narrow therapeutic index, high inter- and intra-individual pharmacokinetic variability, irregular oral bioavailability and require therapeutic drug monitoring (TDM) in order to optimise clinical outcomes after transplantation.9,10 Individual genetic variations and single nucleotide polymorphism in CYP3A4, CYP3A5, PPARA and ABCB1 genes which encode for cytochrome P450 enzymes and p-glycoprotein efflux pumps may significantly compromise the bioavailability of calcineurin 
inhibitors thereby altering blood levels and increasing the chances of acute and/or chronic rejection. ${ }^{11}$

Tacrolimus is generally preferred over cyclosporine for immunosupression in liver transplantation due to multiple reasons, which include higher potency of tacrolimus and less rejection episodes.8,12 However, early employment of tacrolimus in the post-transplantation periods requires vigilant monitoring of drug concentration as serious adverse effects as neurotoxicity and nephrotoxicity can develop during optimization of tacrolimus therapy, especially at higher plasma levels. ${ }^{13}$

The aim of the current study was to evaluate the relationship between tacrolimus blood concentrations and dosage in Pakistani patients undergoing LDLT, and explore the efficacy and tolerability of tacrolimus in terms of immunosuppression and adverse effects using tacrolimus trough levels.

\section{METHODOLOGY}

The study was conducted at Shifa International Hospital, Islamabad, from September 2016 to October 2018. The protocol of the study was approved by the Institutional Review Board. It was an observational prospective study and 60 liver transplant recipients were enrolled in the study after obtaining written informed consent. All LDLTs were performed after approval from human organ transplant authority (HOTA) and ethical committee of the hospital. Baseline characteristics including demographics, medical history, and laboratory profile were recorded for all transplant recipients. Details of the evaluation process of the donors and recipients have been reported elsewhere. 14,15

Immunosupression was initiated approximately 12 hours after the transplantation. As a routine, oral or nasogastric route was used. The standard immunosuppressive agents used at our centre were tacrolimus and steroids; and the initial dose of tacrolimus on the first day after liver transplant was $0.5 \mathrm{mg} /$ day. Venous blood samples of patients were collected in $5 \mathrm{~mL}$ EDTA plastic tubes to measure tacrolimus trough concentrations. The trough levels of tacrolimus were measured as routine protocol on day 3, 6, 9 and 12 using electrochemiluminescence immunoassay (ECLIA). Adjustments in the dose of tacrolimus were made on the basis of the standard of care blood level monitoring of tacrolimus, other clinical indices such as AST, ALT or reporting of adverse effects. Subjects were evaluated until 14 days post-transplantation. Daily laboratory measurements of AST, ALT, alkaline phosphatase, GGT, total bilirubin, serum creatinine, BUN, serum potassium, serum magnesium, blood glucose, albumin, and hematocrit were performed.

In first two weeks post-transplant, tacrolimus trough levels of $7-8 \mathrm{ng} / \mathrm{ml}$ were considered acceptable. In patients with renal insufficiency, other immunosuppressant such as mycophenolate mofetil (MMF) were considered. Outcome was assessed, based on mean tacrolimus trough levels and its impact on adverse outcomes and ACR. Patients in whom tacrolimus trough levels were more than 10 $\mathrm{ng} / \mathrm{ml}$ at least once were also assessed separately.

Collected data was analysed by appropriate statistical methods using Statistical Package for Social Sciences (SPSS V. 22) programme. Students' 't' test was applied for comparison between different groups, continuous variables were specified in mean and SD; whereas categorical variables were described by frequencies, percentages, and computed by Chi-square and Fisher's exact test. A p-value less than 0.05 was considered statistically significant.

\section{RESULTS}

Sixty liver transplant recipients were included, out of which $45(75 \%)$ were males and $15(25 \%)$ were females. Mean age of liver transplant recipients was $49.1 \pm 10.6$ years and male to female ratio was $3: 1$. The most common etiology for end-stage liver disease was HCV in $25(41.7 \%)$ and HBV in $10(16.6 \%)$ patients. Mean tacrolimus dose administered was $0.94 \pm 0.3 \mathrm{mg} /$ day and mean tacrolimus trough levels were $6.1 \pm 2.2 \mathrm{ng} / \mathrm{ml}$. The demographic and clinical data is summarised in Table $\mathrm{I}$.

Table I: Demographic and clinical data.

\begin{tabular}{|c|c|c|}
\hline Variables & $\begin{array}{c}\text { Number } \\
\text { Percentage }\end{array}$ & $(\%)$ \\
\hline \multicolumn{3}{|l|}{ Gender } \\
\hline Male & 45 & 75 \\
\hline Female & 15 & 25 \\
\hline \multicolumn{3}{|l|}{ Etiology } \\
\hline $\mathrm{HCV}$ & 25 & 41.7 \\
\hline HBV, ESLD & 10 & 16.7 \\
\hline HDV & 8 & 13.3 \\
\hline HBV, HDV & 8 & 13.3 \\
\hline Cryptogenic liver cirrhosis, HCC & 2 & 3.3 \\
\hline Other* & 7 & 11.7 \\
\hline Total & 60 & \\
\hline \multicolumn{3}{|l|}{ Ethnicity } \\
\hline Punjabi & 21 & 35 \\
\hline Pathan & 17 & 28.3 \\
\hline Sindhi & 09 & 15 \\
\hline Urdu speaking & 07 & 11.7 \\
\hline Balochi & 4 & 6.7 \\
\hline \multirow[t]{2}{*}{ Gilgit-Baltistan } & 2 & 3.3 \\
\hline & Mean & $\pm \mathrm{SD}$ \\
\hline Age (years) & 49.1 & \pm 10.6 \\
\hline Height $(\mathrm{cm})$ & 168.22 & \pm 7.7 \\
\hline Weight (kg) & 74.1 & \pm 14.5 \\
\hline $\mathrm{BMI}\left(\mathrm{kg} / \mathrm{m}^{2}\right)$ & 26.7 & \pm 5.2 \\
\hline Mean tacrolimus dose (mg/day) & 0.94 & \pm 0.292 \\
\hline Mean tacrolimus trough levels $(\mathrm{ng} / \mathrm{ml})$ & 6.1 & \pm 2.2 \\
\hline Mean tacrolimus trough levels after dose $1(\mathrm{ng} / \mathrm{ml})$ & 4.0 & \pm 3.4 \\
\hline Mean tacrolimus trough levels after dose $2(\mathrm{ng} / \mathrm{ml})$ & 6.0 & \pm 3.7 \\
\hline Mean tacrolimus trough levels after dose $3(\mathrm{ng} / \mathrm{ml})$ & 6.8 & \pm 3.3 \\
\hline Mean tacrolimus trough levels after dose $4(\mathrm{ng} / \mathrm{ml})$ & 7.5 & \pm 2.8 \\
\hline
\end{tabular}


Table II: Mean tacrolimus trough levels in patients with adverse effects and acute cellular rejection $(n=60)$.

\begin{tabular}{lccc}
\hline Variables & $\begin{array}{c}\text { No. of patients } \\
(\%)\end{array}$ & $\begin{array}{c}\text { Tacrolimus trough } \\
\text { levels }(\mathrm{ng} / \mathrm{ml}) \\
(\text { Mean } \pm \text { SD })\end{array}$ & p-value \\
\hline Male recipients & $45(75)$ & $6.10 \pm 2.3$ & 0.87 \\
Female recipients & $15(25)$ & $6.00 \pm 1.9$ & $0.001^{*}$ \\
\hline Sepsis (+) & $16(27)$ & $7.7 \pm 2.5$ & $0.04^{*}$ \\
Sepsis (-) & $44(73)$ & $5.5 \pm 1.9$ & \\
\hline Psychosis (+) & $12(20)$ & $7.2 \pm 2.7$ & 0.28 \\
Psychosis (-) & $48(80)$ & $5.8 \pm 2.1$ & $0.01^{*}$ \\
\hline Seizures (+) & $6(10)$ & $7.03 \pm 3.0$ & \\
Seizures (-) & $54(90)$ & $5.97 \pm 2.2$ & $003^{*}$ \\
\hline Renal insufficiency (+) & $8(13.3)$ & $7.97 \pm 2.9$ &. \\
Renal insufficiency (-) & $52(87)$ & $5.78 \pm 2.0$ & \\
\hline Acute cellular rejection (+) & $9(15)$ & $4.05 \pm 1.6$ & \\
Acute cellular rejection $(-)$ & $51(85)$ & $6.43 \pm 2.2$ & \\
\hline
\end{tabular}

Table III: Comparison of adverse effects, sepsis and acute cellular rejection in patients with tacrolimus trough levels greater than $10 \mathrm{ng} / \mathrm{ml}(\mathrm{n}=60)$.

\begin{tabular}{lccc}
\hline & $\begin{array}{c}\text { Tacrolimus levels } \\
>10 \mathrm{ng} / \mathrm{ml}(\mathrm{n}=24)\end{array}$ & $\begin{array}{c}\text { Tacrolimus levels } \\
\leq 10 \mathrm{ng} / \mathrm{ml}(\mathrm{n}=36)\end{array}$ & p-value \\
\hline Adverse effects (+) & $13(54.1)$ & $4(11.1)$ & $<0.001^{*}$ \\
Adverse effects (-) & $11(45.9)$ & $32(88.9)$ & \\
\hline Sepsis (+) & $12(50)$ & $4(11.1)$ & $0.002^{*}$ \\
Sepsis (-) & $12(50)$ & $32(88.9)$ & \\
\hline Acute cellular rejection (+) & 0 & $9(25)$ & $0.008^{*}$ \\
Acute cellular rejection $(-)$ & $24(100)$ & $27(75)$ & \\
\hline
\end{tabular}

There was a significant difference in mean tacrolimus levels in patients with and without ACR $[4.05 \pm 1.6 \mathrm{ng} / \mathrm{ml}$ versus $6.4 \pm 2.2 \mathrm{ng} / \mathrm{ml},(\mathrm{p}=0.003)$ ] as shown in Table II. Similarly, a significant difference in mean tacrolimus levels was observed in patients with and without sepsis $[7.7 \pm 2.5 \mathrm{ng} / \mathrm{ml}$ versus $5.5 \pm 1.9 \mathrm{ng} / \mathrm{ml}(\mathrm{p}=0.001)]$, psychosis $[7.2 \pm 2.7 \mathrm{ng} / \mathrm{ml}$ versus $5.8 \pm 2.1 \mathrm{ng} / \mathrm{ml}(p=0.04)]$ and renal insufficiency $[7.9 \pm 2.9 \mathrm{ng} / \mathrm{ml}$ versus $5.7 \pm 2 \mathrm{ng} / \mathrm{ml}$ $(p=0.01)]$. Pearson correlation test found no impact of $\mathrm{BMI}$ on tacrolimus trough levels.

Twenty-four out of 60 patients had tacrolimus trough levels more than $10 \mathrm{ng} / \mathrm{ml}$ at least once during 14 days post transplant. Episodes of adverse events 13/24 $(54.1 \%)$ versus $4 / 36(11.11 \%, p<0.001)$, sepsis $12 / 24$ $(50 \%)$ versus $4 / 36(11.11 \% p=0.002>$ and ACR 0 versus $9 / 36(25 \%, p=0.008)$ were significantly more common in these patients are shown in Table III.

\section{DISCUSSION}

A high number of male transplant recipients in the current study is in agreement with other studies which have highlighted different factors for the uneven gender distribution for transplant candidacy. These include prevalence of HCC in males and imperfect model for end-stage-liver disease (MELD) score which uses serum creatinine. Levels of serum creatinine are higher in males because of higher body muscle mass. ${ }^{16-18}$ Nevertheless, there was no significant effect of gender and BMI on mean tacrolimus trough levels.
The major ethnic groups in our study population were Punjabi and Pushto speaking. This by no means suggests that liver failure or HCC is more prevalent in this patient group. In fact, we believe that easy access to the transplant centre due to its location in northern part of the country was responsible for this ethnic distribution.

Titrating the dose of tacrolimus to optimum levels in liver transplant recipients is a challenging task as lower than therapeutic plasma levels can result in ACR; whereas, higher plasma levels can lead to serious adverse effects such as nephrotoxicity, neurotoxicity and increased risk of acquired infections. In this study, tacrolimus was titrated to achieve optimal levels in plasma and consequently the dosages of tacrolimus varied in different patients. The mean dosage of tacrolimus administered for the first 14 days after liver transplant in all patients was $0.94 \mathrm{mg} /$ day. Mean tacrolimus trough levels reported in this study are $6.1 \pm 2.2 \mathrm{ng} / \mathrm{ml}$. These levels are considerably lower than the mean values reported from other studies conducted in China $(11.3 \pm 4.8 \mathrm{ng} / \mathrm{ml})$ and India $(7.3 \pm 2.9 \mathrm{ng} / \mathrm{ml})$ in live donor liver transplant patients. ${ }^{18,19}$ Variable metabolism of tacrolimus due to underlying genetic polymorphism could be possible reason for different tacrolimus trough levels in different populations.

Sepsis, psychosis, seizures and renal insufficiency appeared to be the common adverse effects and mean trough tacrolimus levels in these recipients were lower than other studies reporting similar adverse effects. In different studies, occurrence of adverse effects was reported at high tacrolimus trough concentration or even higher than the therapeutic concentration of $15 \mathrm{ng} / \mathrm{ml}$. 19,20 In this study, 27\% recipients developed sepsis and mean tacrolimus trough levels in these patients were significantly higher than other recipients without acquired infection. Similarly, recipients who developed renal insufficiency and neurotoxicity also had significantly higher mean tacrolimus trough levels. These results are consistent with results of other transplant programmes which have reported similar frequency of sepsis and other tacrolimus related adverse events. 19,2123 However, the unique point in the current study is the lower cut off level at which adverse events were noted.

This study reported $15 \%$ acute cellular rejection in liver transplant recipients, which is consistent with other studies. ${ }^{24}$ Mean tacrolimus trough levels in patients with acute rejection were $4.05 \pm 1.6 \mathrm{ng} / \mathrm{ml}$ as compared to $6.43 \pm 2.2 \mathrm{ng} / \mathrm{ml}$ in patients with no rejection. Mean trough levels of tacrolimus in our population without rejection are quite low. 25 Thus, on the basis of our results we can safely recommend tacrolimus trough levels to be in the range of $5 \mathrm{ng} / \mathrm{ml}$ to $7 \mathrm{ng} / \mathrm{ml}$ to balance risk of acute rejection versus adverse events.

Recent studies have emphasised the importance of unique dosing protocols for tacrolimus-based immuno- 
supression, hinting towards the possibility of genetic polymorphism in drug metabolism across certain patient populations. This study provides data from liver transplant recipients in Pakistan necessitating future molecular and clinical studies to establish national guidelines for effective use of tacrolimus with minimum adverse effects.

\section{CONCLUSION}

Pakistani liver transplant patients show varying pharmacokinetic properties. Lower than expected tacrolimus levels are able to achieve desired results with minimal risk of toxicity. A tacrolimus trough level between 8-12 $\mathrm{ng} / \mathrm{ml}$ is not required in our population. This has a huge impact considering high cost of the drug and risks of adverse effects with high levels.

\section{ETHICAL APPROVAL:}

Ethical approval was obtained from the Institutional Review Board \& Ethics Committee (IRB \#: 638-086-2016), Shifa International Hospital Islamabad.

\section{PATIENTS' CONSENT:}

Informed consents were taken from all patients prior to enrollment in the study.

\section{CONFLICT OF INTEREST:}

Authors declared no conflict of interest.

\section{AUTHORS' CONTRIBUTION:}

FA: Conceived and designed study, collected, analyzed and interpreted data; drafted manuscript

MK: Designed study, interpreted data and drafter manuscript, reviewed final draft.

$\mathrm{ABH}$ : Designed study, collected, analysed and interpreted data; drafted manuscript, reviewed final draft

FSD: Designed study, interpreted data; drafted manuscript. AA: Designed study, interpreted data; drafted manuscript. $\mathrm{NJ}$ : Collected and analysed data.

\section{REFERENCES}

1. Dutkowski P, Linecker M, De Oliveira ML, Müllhaupt B, Clavien PA. Challenges to liver transplantation and strategies to improve outcomes. Gastroenterology 2015; 148:307-23.

2. Young K, Liu B, Bhuket T, Younossi Z, Saab S, Ahmed A, et al. Long-term trends in chronic hepatitis $B$ virus infection associated liver transplantation outcomes in the United States. J Viral Hepat 2017; 24:789-96.

3. Ali SA, Donahue RMJ, Qureshi H, Vermund SH. Hepatitis B and hepatitis $\mathrm{C}$ in Pakistan: Prevalence and risk factors. Int $\mathrm{J}$ Infect Dis 2009; 13:9-19.

4. Kanaani ZA, Mahmud S, Kouyoumjian SP, Abu-Raddad LJ. The epidemiology of hepatitis $C$ virus in Pakistan: systematic review and meta-analyses. $R$ Soc Open Sci 2018; 5:180257.

5. Bhatti $A B H$, Dar FS. Living donor liver transplantation in Pakistan. Transplantation 2017; 101:1507-8.
6. Mathur AK, Talwalkar J. Quality measurement and improvement in liver transplantation. J Hepatol 2018; 68:1300-10.

7. Elad S, Epstein JB, Yarom N, Drucker S, Tzach R, von Bültzingslöwen I. Topical immunomodulators for management of oral mucosal conditions, a systematic review; part I: calcineurin inhibitors. Expert OpinEmerg Drugs 2010; 15:713-26.

8. Kelly PA, Burckart GJ, Venkataramanan R. Tacrolimus: A new immunosuppressive agent. Am J Health Syst Pharm 1995; 52:1521-35.

9. Undre NA, Stevenson P, Schäfer A. Pharmacokinetics of tacrolimus: Clinically relevant aspects. Transplant Proc 1999; 31: 21S-24S.

10. Venkataramanan R, Swaminathan A, Prasad T, Jain A, Zuckerman $\mathrm{S}$, Warty $\mathrm{V}$, et al. Clinical pharmacokinetics of tacrolimus. Clin Pharmacokinet 1995; 29:404-30.

11. Debette-Gratien M, Wolliard JB, Picard N, Sebagh $M$, Loustaud-Ratti V, Sautereau D, et al. Influence of donor and recipient CYP3A4, CYP3A5, and ABCB1 genotypes on clinical outcomes and nephrotoxicity in liver transplant recipients. Transplantation 2016; 100:2129-37.

12. Budde K, Glander P. Pharmacokinetic principles of immunosuppressive drugs. Ann Transplant 2008; 13:5-10.

13. Tolou-Ghamari Z, Palizban A, Tredger J. Modelling tacrolimus AUC in acute and chronic liver disease immediately after transplant. Transplantationsmedizin 2004; 16.Jahrg., S. 110.

14. Dar FS, Bhatti ABH, Dogar AW, Zia H, Amin S, Rana A, et al. The travails of setting up a living donor liver transplant program: Experience from Pakistan and lessons learned. Liver Transplantation 2015; 21:982-90.

15. Dar FS, Zia H, Bhatti ABH, Rana A, Nazer R, Kazmi R, et al. Short-term donor outcomes after hepatectomy in living donor liver transplantation. J Coll Physicians Surg Pak 2016; 26:272-6.

16. Rodríguez-Castro KI, Martin ED, Gambato M, Lazzaro S, Villa E, Burra P. Female gender in the setting of liver transplantation. World J Transplant 2014; 4:229-42.

17. Puoti F, Ricci A, Nanni-Costa A, Ricciardi W, Malorni W, Ortona E. Organ transplantation and gender differences: A paradigmatic example of intertwining between biological and sociocultural determinants. Biol Sex Differ 2016; 7:35.

18. Oloruntoba OO, Moyla CA. Gender-based disparities in access to and outcomes of liver transplantation. World J Hepatol 2015; 7:460-7.

19. Varghese J, Reddy MS, Venugopal K, Perumalla R, Narasimhan G, Arikichenin O, et al. Tacrolimus-related adverse effects in liver transplant recipients: Its association with trough concentrations. Indian J Gastroenterol 2014; 33:219-25.

20. Wu Z, Meng Q, Xia Y, Zhang F, You W. A retrospective analysis of the safety and efficacy of low dose tacrolimus (FK506) for living donor liver transplant recipients. J Biomed Res 2013; 27):305-9.

21. Emre S, Genyk Y, Schluger LK, Fishbein TM, Guy SR, Sheiner PA, et al. Treatment of tacrolimus-related adverse effects by conversion to cyclosporine in liver transplant recipients. Transpl Int 2000; 13:73-8.

22. Nacif LS, David AI, Pinheiro RS, Diniz MA, Andraus W, Junior RJC, 
et al. An analysis of tacrolimus-related complications in the first 30 days after liver transplantation. Clinics (Sao Paulo) 2014; 69:745-749.

23. Fagiuoli S, Colli A, Bruno R, Craxì A, Gaeta GB, Grossi P, et al. Management of infections pre- and post-liver transplantation: Report of an AISF consensus conference. J Hepatol 2014; 60:1075-89.
24. Dogan N, Hüsing-Kabar A, Schmidt HH. Cicinnati VR, Beckebaum S, Kabar I. Acute allograft rejection in liver transplant recipients: Incidence, risk factors, treatment success, and impact on graft failure. J Int Med Res 2018; 46:3979-90.

25. Li C, Li L. Tacrolimus in preventing transplant rejection in Chinese patients - optimizing use. Drug Des Devel Ther 2015; 9:473-85.

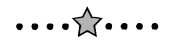

